\title{
Match Study on Personnel Policy and Science Technology Human Resource of Strategic Emerging Industries
}

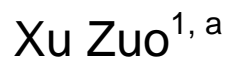 \\ ${ }^{1}$ University of Technology, Hefei, Anhui, China, 230009
}

\begin{abstract}
Keywords: Strategic Emerging Industries, R \& D Personnel, Human Resources Policy
\end{abstract}
\begin{abstract}
Science technology and human resources are the most valuable strategic resources for industrial development and it is to promote the industrial development of the key factors. Strategic emerging industries in order to rapid development, it requires science and technology human resources' policy that matches people for support. This article is based strategic industries and emerging talent status quo policy, combing the existing literature summarizes the representative of the personnel policy, research and technology human resource personnel policy match, the policy-oriented aspect of the proposed science and technology human resource policy measures recommended, in order to reform the existing strategic emerging industries, science and technology human resource management, development patterns play a reference role.
\end{abstract}

\section{Introduction}

In recent years, China's economy has maintained a rapid growth rate, but with most of the traditional industry into a mature stage of development or decline, economic growth will be gradually transferred to the low-speed period. The traditional mode of economic development resource consumption, environmental pollution is high. October 2010, the State Council issued the "State Council on accelerating the cultivation and development of strategic emerging industries", the first policy document in the manner determined strategic emerging industries industry category, tasks of development and policy support. Foster and develop strategic emerging industries as a solution to the country's current economic development bottleneck of major strategic initiatives have been proposed, this strategic move has aroused extensive attention. And actively respond to national call provinces have also developed in line with the region's actual strategic planning of new industries.

Combining science and technology and human resources, is seen as a key factor in competition and economic development of a country to keep up with rapid changes in science and technology, to meet new challenges, we need a growing art and highly efficient workforce. So, science and technology human resource is a valuable strategic resource industry. To maximize the utilization of science and technology human resources requires a set of human resources and technology to match the personnel policy for support. So Talent Technology Human Resource Policy and practical level match is very important.

\section{The Research Status}

Strategic emerging industries is a major technological breakthrough and major development needs, based on the overall situation and long-term economic and social development have a significant leading role, knowledge and technology-intensive, less consumption of material resources, growth potential, comprehensive benefits good industry. The United States in 2009, promulgated the "American Innovation Strategy: promoting sustainable growth and provide an excellent working opportunity," "reforming the framework of American manufacturing," clearly will be clean energy, health care, biotechnology, nanotechnology, advanced automotive, aerospace etc., as key development areas for the next 20 years. Britain also in 2009 introduced the "build Britain's future," the planning, preparation in a low-carbon economy, bio-industry, life sciences, and other fields to break the digital economy. Japan proposed a "brilliant for Japan's new growth strategy," focusing on the development of environmentally friendly vehicles, electric vehicles, medical and nursing care, 
cultural tourism and solar power and other industries. Wen Jiabao pointed out that in 2009, the development of new strategic industries, China is based on the current tide over the crisis, focusing on the major long-term strategic choice level to an international perspective and strategic thinking to select and develop new strategic industries. He pointed out that in 2012, to strengthen the emerging industries of strategic top-level design and scientific layout. Jiang World Bank (2005), the regional strategic industries is related to economic development and regional structure rationalization key strategic industries, global and long-term nature of the industry; Mawu Song (2010) believes that the "post-crisis era", the strategic emerging industries is China's economic development.

Talent has become the primary resource for economic development and social progress. HRST as human resources is an important part of a country or a region with a strong science and technology management, research and development capabilities and expertise capacities of people in general. With the emerging industries of strategic reserves of talent is increasing, by the end of 2014, the total amount of "science and technology engineering and technical personnel," the country has more than one million people. In recent years, more and more companies to develop human resources policies targeting human resources management is the most important part. Define human resources policies have a lot of money Discovering (2004) and so that human resources management policies refers to the guiding principles and operational guidelines deal with issues related to employee executives and human resource management departments to develop. "Think tank Wikipedia" definition of human resources policies on human resources is the acquisition, development, distribution, uses and maintains the company's policy in order to achieve business goals and develop. Liu Bin (2015) all of the content that the human resources policies are designed around people began to unfold, including the selection system of personnel training and development system, employee incentive system, assessment appraisal system, so a variety of bonuses and employee welfare system the vital interests of policy-related. Policymakers are reasonable, personal development staff have the most direct impact. Enterprise development and growth, we must constantly improve the internal human resources policies, from the personal interests of employees, so as to attract more people with lofty ideals, thereby creating more economic benefits for the company. Therefore, we should vigorously develop strategic emerging industries, it is necessary to use a set of matching personnel policy for support. Maintaining coordination between the two, to solve the shortage of talent, and serious brain drain problem, and give full play to the role of talent to pull the adjustment of industrial structure, the basic conditions for economic development and industrial upgrading of the industrial structure optimization.

\section{The Model Building}

Match measure process Personnel Policy and Technology Human Resource between difficult to express, in order to study the availability of data, in order to make it easier for respondents to understand, this paper introduces the psychological concept of "satisfaction", which is indicates that a comparison between reality and expectations feelings. Through the development of science and technology human resource of the enterprise personnel policy satisfaction survey to obtain matching we want to get the talent and technology of human resources policy between the paper argues that the higher science and technology human resource policy for talent satisfaction so talent match policy on science and technology human resource is higher. As used herein, "customer satisfaction" as the core concept developed by Swedish Customer Satisfaction Barometer index (Sweden Customer Satisfaction Barometer, SCSB) overall evaluation model is based on science and technology human resources personnel policy, "consumption" to examine the whole process. The matching process and technology human resource personnel policy is regarded as among business and technology between the human resources process "deal" on personnel policy, "transaction" satisfaction study aimed at identifying currently affecting Match factors, targeted improve the personnel policy.

Design the Questionnaire. According to the results of previous studies found combing the impact of scientific and technological development of emerging industries of strategic human 
resource policy support for the work, pay and performance appraisal, training and career development, working conditions and other aspects of vacation. These policies act on the internal configuration of the human resources industry, through the enterprise staff recruitment, use, training, evaluation, motivation and so a series of adjustment processes, the impact of employee job satisfaction and thus affect their enthusiasm for work, create value aspects of capacity, and finally affect the development of the whole industry.

Select the variable. To make personnel involved in the investigation of a better understanding, we have the "satisfaction" of science and technology human resources survey, reflecting their HRST where the degree of matching business people policies. Through the research and analysis of the application of a number of scholars, Hoppock (1935) that the job satisfaction factors are working conditions, monotonous, fatigue, leadership and so on. Volk-wein (1998) that the employee satisfaction factors related to the work itself is divided into internal factors (self-efficacy, recognition and Innovation initiative, challenging work, etc.) and external factors work (remuneration, working environment, safety, opportunities for promotion, stress, organizational policies, etc.) as well as interpersonal factors (superior-subordinate relationship, relationship with colleagues, etc.). Cao Minghua (2013) empirical study of the impact through the use of factor analysis, that the attitude of employees, employees expect job-hopping trend, job performance and other factors for the satisfaction of. Learn from the above references and Human Resources policy-relevant indicators selected the following questionnaire design.

Table 1 Human resource policies match degree beginning measurement index system

\begin{tabular}{|c|c|c|}
\hline First indicators & Secondary indicators & Third indicators \\
\hline \multirow{6}{*}{$\begin{array}{l}\text { Work itself related } \\
\text { to internal factors }\end{array}$} & \multirow{3}{*}{ Self-efficacy } & Enterprise development goals \\
\hline & & company culture \\
\hline & & Enterprise management system \\
\hline & \multirow{3}{*}{ Work Challenge } & He considered the work challenging \\
\hline & & The resulting sense of achievement at work \\
\hline & & Career development \\
\hline \multirow{13}{*}{$\begin{array}{l}\text { Work external } \\
\text { factors }\end{array}$} & \multirow{2}{*}{ Work support } & $\begin{array}{l}\text { New products and the degree of emphasis on new } \\
\text { technology development }\end{array}$ \\
\hline & & $\begin{array}{l}\text { Enterprises to provide all necessary information on } \\
\text { the speed }\end{array}$ \\
\hline & \multirow{4}{*}{$\begin{array}{l}\text { Remuneration and } \\
\text { Appraisal }\end{array}$} & Salary \\
\hline & & Corporate welfare \\
\hline & & Promotion mechanisms \\
\hline & & Performance appraisal system \\
\hline & \multirow{2}{*}{$\begin{array}{l}\text { Recruitment, Training } \\
\text { and Development }\end{array}$} & Recruitment and dismissal system \\
\hline & & Training opportunities \\
\hline & \multirow{3}{*}{$\begin{array}{l}\text { Working conditions } \\
\text { and vacations }\end{array}$} & $\begin{array}{l}\begin{array}{l}\text { Enterprises working environment and working } \\
\text { conditions }\end{array} \\
\end{array}$ \\
\hline & & $\begin{array}{l}\text { The company offers a complete work necessary } \\
\text { facilities and equipment }\end{array}$ \\
\hline & & Working hours and rest periods \\
\hline & \multirow[b]{2}{*}{ Relationships } & Communication and exchange among colleagues \\
\hline & & $\begin{array}{l}\text { Happy efficiency level of cooperation among } \\
\text { colleagues / co-workers get along }\end{array}$ \\
\hline
\end{tabular}

Sample Selection and Data Sources. Consider the availability of data subjects, the researchers' randomly selected 33 high-tech zones in Anhui emerging industries of strategic companies in the sample. Anhui Province has not been announced because the domain of strategic and emerging business directories, to determine whether the listed companies belonging to strategic emerging industries, so the selected enterprises in Anhui province in which the industry is divided into eight strategic emerging industries and industry segments. The survey taken in the form of paper questionnaires distributed, a total of 700 questionnaires, 658 questionnaires, of which 637 valid 
questionnaires, the effective rate was $91 \%$.

\section{The Descriptive Statistical Analysis}

Table 2 shows the sample to males (72.2\%), mainly young (35 years of age accounted for 79.2\%), higher education (college education accounted for 96.2\%), technical staff posts to the main (62.3\%).

Table 2 Sample Demographic Characteristics

\begin{tabular}{|c|c|c|c|c|}
\hline Divisions & Category & $\begin{array}{l}\text { Number } \\
\text { of people }\end{array}$ & Percentage & $\begin{array}{l}\text { Cumulative } \\
\text { Percentage } \\
\end{array}$ \\
\hline \multirow{2}{*}{ Gender } & Male & 460 & $72.20 \%$ & $72.20 \%$ \\
\hline & Female & 177 & $27.80 \%$ & $100.00 \%$ \\
\hline \multirow{5}{*}{ Age } & 25 years of age (inclusive) & 149 & $23.40 \%$ & $23.40 \%$ \\
\hline & 26-30 years old & 252 & $39.60 \%$ & $63.00 \%$ \\
\hline & 31-35 years old & 103 & $16.20 \%$ & $79.20 \%$ \\
\hline & 36-45 years old & 31 & $4.80 \%$ & $84.00 \%$ \\
\hline & 45 years of age & 102 & $16 \%$ & $100.00 \%$ \\
\hline \multirow{5}{*}{$\begin{array}{l}\text { Education } \\
\text { Level }\end{array}$} & $\begin{array}{l}\text { High school (secondary } \\
\text { school) and below }\end{array}$ & 24 & $3.80 \%$ & $3.80 \%$ \\
\hline & College & 95 & $14.90 \%$ & $18.70 \%$ \\
\hline & Undergraduate & 398 & $62.50 \%$ & $81.20 \%$ \\
\hline & Master's Degree & 108 & $17 \%$ & $98.20 \%$ \\
\hline & Dr. and Above & 12 & $1.80 \%$ & $100.00 \%$ \\
\hline \multirow{4}{*}{ Position } & Senior management & 27 & $4.20 \%$ & $4.20 \%$ \\
\hline & Middle managers & 86 & $13.50 \%$ & $17.70 \%$ \\
\hline & Technical staff & 397 & $62.30 \%$ & $80.00 \%$ \\
\hline & General Staff & 127 & $20 \%$ & $100.00 \%$ \\
\hline \multirow{4}{*}{ Seniority } & $0-5$ Years & 346 & $54.30 \%$ & $54.30 \%$ \\
\hline & 6--10 years & 176 & $27.60 \%$ & $81.90 \%$ \\
\hline & 11--15 years & 70 & $11 \%$ & $92.90 \%$ \\
\hline & More than 16 years & 45 & $7.10 \%$ & $100.00 \%$ \\
\hline \multirow{4}{*}{$\begin{array}{l}\text { Monthly } \\
\text { Income }\end{array}$} & 3,000 yuan & 119 & $18.70 \%$ & $18.70 \%$ \\
\hline & $3000-4000$ yuan & 212 & $33.30 \%$ & $52.00 \%$ \\
\hline & 4000-5000 yuan & 108 & $17.00 \%$ & $69.00 \%$ \\
\hline & More than 5,000 & 197 & $31.00 \%$ & $100.00 \%$ \\
\hline \multirow{9}{*}{ Subject } & Law & 10 & $1.60 \%$ & $1.60 \%$ \\
\hline & Engineering & 384 & $60.30 \%$ & $61.90 \%$ \\
\hline & Management & 45 & $7.10 \%$ & $69.00 \%$ \\
\hline & Pedagogic & 4 & $0.60 \%$ & $69.60 \%$ \\
\hline & Economics & 13 & $2.00 \%$ & $71.60 \%$ \\
\hline & Natural & 112 & $17.60 \%$ & $89.20 \%$ \\
\hline & Agronomy & 4 & $0.60 \%$ & $89.80 \%$ \\
\hline & Medicine & 7 & $1.10 \%$ & $90.90 \%$ \\
\hline & Other & 58 & $9.10 \%$ & $100.00 \%$ \\
\hline
\end{tabular}

\section{Data Analysis}

Data Quality Inspection. Use SPSS software for data analysis, data quality first questionnaire were validity, reliability test. 
The questionnaire validity. SPSS software application samples KMO measure and Bartlett test. As shown in Table $4 \mathrm{KMO}$ value is 0.963 , the larger the value, the better for factor analysis. Generally considered greater than 0.5 , the data do factor analysis. 0.963 is far greater than 0.5 , indicating that the collected data suitable for factor analysis. From Bartlett's test at the same time, a significant coefficient is less than 0.001 . Therefore, the questionnaire has acceptable validity, factor analysis can be performed.

Table $3 \mathrm{KMO}$ and Bartlett's test

\begin{tabular}{|lcr|r|}
\hline $\begin{array}{l}\text { Adequate } \\
\text { measure }\end{array}$ & sampling of the Kaiser-Meyer-Olkin & .963 \\
Bartlett test $\quad$ of $\quad$ Chi-square approximation & 9671.535 \\
sphericity & df & 231 \\
& Sig. & .000 \\
\hline
\end{tabular}

The questionnaire reliability test. This study uses Cronbach' $\alpha$. Reliability coefficient value judgment principle, which divided the lowest level of internal consistency coefficient $\alpha$ to be above 0.50, preferably above 0.60 , and the entire amount of the table minimum internal consistency coefficient $\alpha$ to be 0.70 or more, preferably high 0.80 .

In this study, the reliability analysis results in Table 5 , it can be seen that each item in a hierarchical title, refer to two heading Cronbach' $\alpha$ coefficient values were greater than 0.7; Cronbach' $\alpha$ whole weight coefficient table value of 0.958 . Therefore, it can determine the internal science and technology human resource policy questions of various factors by examining the consistency between the high reliability of the survey questionnaire.

Table 4 Questionnaire reliability test results

\begin{tabular}{c|c|c}
\hline & \multicolumn{2}{|c|}{ Cronbach' $\alpha^{\prime}$} \\
\hline Self-efficacy & 0.868 \\
\hline Challenging work & 0.853 \\
\hline $\begin{array}{c}\text { Work support } \\
\text { Appraisal }\end{array}$ & 0.782 & 0 \\
\hline $\begin{array}{c}\text { Recruitment, Training and } \\
\text { Development }\end{array}$ & 0.903 \\
\hline $\begin{array}{c}\text { Working conditions and } \\
\text { vacations }\end{array}$ & 0.758 & \\
\hline Relationships & 0.801 & \\
\hline
\end{tabular}

Personnel policies on science and technology human resource match index analysis. To find the study on the impact of the internal mechanism of personnel policies of talent between the two indicators were correlated with results of the analysis are shown in Table 6.

Table 5 Pearson correlation analysis between the personnel policy indicators

\begin{tabular}{|c|c|c|c|c|c|c|c|}
\hline & $\begin{array}{l}\text { Organization } \\
\text { efficacy }\end{array}$ & $\begin{array}{c}\text { Challenging } \\
\text { work }\end{array}$ & $\begin{array}{l}\text { Work } \\
\text { support }\end{array}$ & $\begin{array}{l}\text { Remuneration } \\
\text { and Appraisal }\end{array}$ & $\begin{array}{l}\text { Recruitment, } \\
\text { Training and } \\
\text { Development }\end{array}$ & $\begin{array}{c}\text { Working } \\
\text { conditions and } \\
\text { vacations }\end{array}$ & Relationships \\
\hline $\begin{array}{l}\text { Organization } \\
\text { efficacy }\end{array}$ & 1 & & & & & & \\
\hline $\begin{array}{c}\text { Challenging } \\
\text { work }\end{array}$ & $0.717^{* *}$ & 1 & & & & & \\
\hline Work support & $0.753^{* *}$ & $0.667^{* *}$ & 1 & & & & \\
\hline $\begin{array}{l}\text { Remuneration } \\
\text { and Appraisal }\end{array}$ & $0.755^{* *}$ & $0.782^{* *}$ & $0.702^{* *}$ & 1 & & & \\
\hline Recruitment, & $0.737^{* *}$ & $0.774^{* *}$ & $0.664^{* *}$ & $0.786^{* *}$ & 1 & & \\
\hline $\begin{array}{l}\text { Development } \\
\text { Working } \\
\text { conditions } \\
\text { and vacations }\end{array}$ & $0.693^{* *}$ & $0.667^{* *}$ & $0.678^{* *}$ & $0.715^{* *}$ & $0.671^{* *}$ & 1 & \\
\hline
\end{tabular}


Significant at the 0.01 level (two-tailed), significantly correlated.

The data in Table 6 from the display shows that significant levels of all indexes of 0.01 or less, correlations have reached more than 0.5 , indicating a clear correlation.

\section{Conclusions and Recommendations}

Match case two indicators shown in Figure 1. Overall, the relationship is of the highest degree of matching. Remuneration and Appraisal of matching the lowest in living standards mainly immigrant settlement infrastructure, public service facilities to be much better than before relocation; social adaptation due to the migration are from the village to the town, county relocation, and scattered resettlement immigrants, but also a few families emigrated moved to a new place, the interviews also showed that immigrants adapt to the social resettlement little effect on satisfaction.
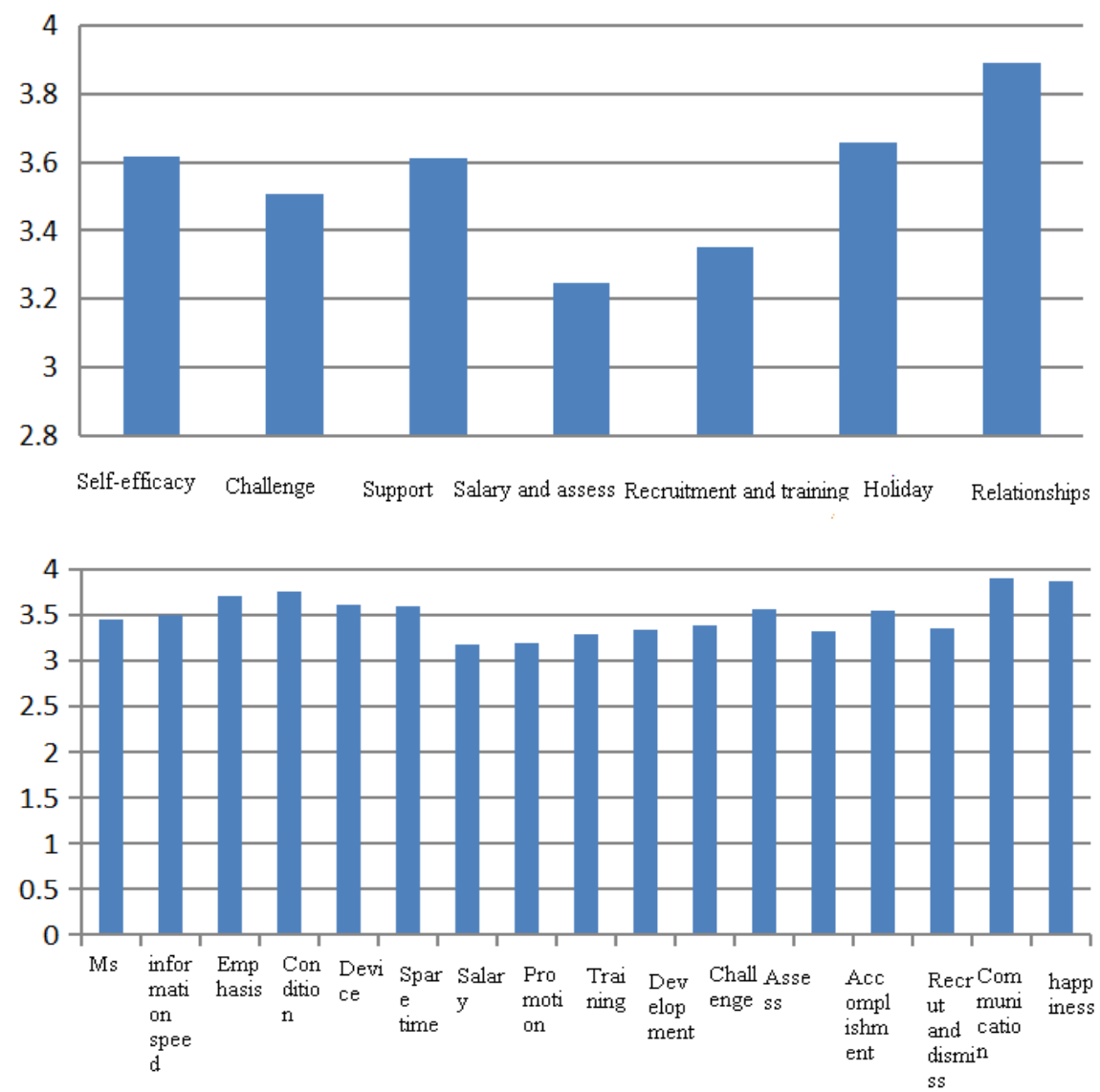

R \& D personnel in human resources policies as satisfaction of our human resources for science and technology human resource policies match. The number of patents per capita reflects the development of strategic emerging industries, the higher the per capita number of patents, industrial development and the better. The above analysis results can be seen in the matching sort above statistics by industry R \& D personnel per capita number of patents consistent. That science and technology human resource of matching human resources policy and industrial development were positively correlated. Therefore, the development of strategic new industries must improve the strategic emerging industry personnel policy, improve the matching degree is the key talent and policies. Match only by improving the scientific and technological human resources and human resources policies in order to reduce the brain drain, in order to retain talent, strategic emerging industry talent advantage and then be promoted; strategic emerging industries so as to ensure sound and rapid development.

In addition, we see that through the analysis, strategic emerging industries and science and technology human resource human resource policies Match Overall distributed between 3-4 minutes between ships and satisfaction that is between, and are not satisfactory. Match Overall 
salaries and benefits of the lowest especially machinery manufacturing industry matching this indicator is 3 points.

The impact of pay and benefits in terms of matching between employees and human resources policy is relatively large, the level of direct standard of living and quality of life based on the current economic development in Anhui strength and the standard of living, salaries and benefits of the affected residents, matching this indicator Anhui Province machinery manufacturing showed the lowest salary is not competitive, the survey, salary survey by the staff (including wages, bonuses, etc.) and Jiangsu and Zhejiang worse than about 20\%. In addition to the survey who have ordinary skill also pay the difference between their R \& D managers and other senior officers reached 1.5 times, R \& D personnel in mostly ordinary skill from some extent they psychological gap will be relatively large so results in lower satisfaction with compensation and benefits.

Compensation includes not only the salary, bonus, also includes various welfare, improve the matching of its staff and human resources policies have a crucial role. From the practice of human resource management point of view, to make employees pay satisfaction, must comply with pay equity, both with respect to other organizations with similar staff positions resulting fair salary that is external equity, including colleagues within the organization with respect to income fair salaries. Therefore, we need to take the following measures.

(1) enterprise itself reasonable salary system, companies can open the company's operating performance for employees to learn more about the company operating conditions, etc., so that employees fully understand the relationship between business conditions and wages. HR can also be published on a regular basis in different jobs in the local pay level reports, and comparison with the wage level of the enterprise, to justify the enterprise staff salaries.

(2) Enterprises pay system is unreasonable. The survey also found that the average monthly salary is R \& D department manager of ordinary skill in the average monthly salary is 1.5 times. There are a lot of companies the situation in the presence of seniority pay, even on their pay level is not low, but seeing strong ability to work without their own old staff get pay with their almost time, it will produce psychological imbalance. This salary system for employees has lost incentives, companies can according to the actual situation, takes the redesign by themselves or outsourced to professional human resources company, etc. to establish their own remuneration system.

\section{References}

[1] Zhang Lingyun. China Science and Technology Human Resource Configuration [J] East China Science and Technology, 2006 (2): 24

[2] Zhang Xiaoli. Strategic emerging industries of high-level personnel training System [J] Higher Education of 2013 (12): 123-125

[3] Yang Weilin. On the rational distribution of regional strategic and industrial structure [J] Sichuan Administration College, 2005 (4): 62-65

[4] Jiang Shiyin. The overall layout of the Western Region of Strategic Industrial Structure [J] Finance \& Economics, 2005 (6): 11-15

[5] Ma Wusong. The "post-crisis era" China's economic development strategy: strategic emerging industries step up the layout [J] Technology Industry of China, 2010 (5): 50-53

[6] Qian Zhenbo. Discovering human resource management theory • Policy • Practice [M] Beijing: Tsinghua University Press, 2004: 36

[7] Liu Bin. The modern human resources policies and internal control environment analysis [J] Human Resource Management, 2015 (6): 3 